\section{ARCHIVES OF THE LAKES}

$\mathrm{W}$ $\mathrm{E}$ are just now being made aware that there exists a remarkable series of records of the history of Europe throughout the whole period since the great ice sheets began to release their hold on the Continent. These records are entombed in the deposits of our lake basins. We have hitherto been unable to read these archives; but the methods of pollen-analysis have given us the clue to their broad interpretation, and the story of forest history, of climatic change, and of human activity is discerned with increasing clarity. We have learned from de Geer that these records can, in some circumstances, be accurately dated; the lake deposits sometimes indeed consist of leaves, one page laid down per year, so that a precise geochronology of the past ten thousand years or so has been placed in the hands of the archivist.

A glimpse of the remarkable wealth of information such records may disclose is afforded by the recently published work of Max Welten on the deposits of a single tiny filled-up lake basin in the Simmental in the western Bernese Oberland ${ }^{1}$. This Faulenseemoos lies at a height of $590 \mathrm{~m}$. above sea-level, on the road. between Spiez and Interlaken, and here M. Welten, a pupil of Dr. Lüdi in Zurich, has carried out coordinated research on pollen-analysis, stratigraphy, and geochronology. Twelve detailed pollen-diagrams, distributed along a profile of the lakelet's length, which is only about $500 \mathrm{~m}$., give a complex but consistent picture of the vegetational history of the region round the lake, which has been steadily filling in throughout post-glacial and late-glacial times. The lake was oligotrophic only for a short while, and then rapid infilling took place from land surfaces laid bare by the glacial retreat. With complete vegetational cover of the countryside, however, the infilling became slower. Heavy deposits of lake chalk were made round the shallow margins while the deep centre deposits grew very slowly, and then, as the climate grew warmer, organic material formed too rapidly for total oxidation aud nekron-mud (gyttja) was laid down. Thence followed a yearly periodicity of chalk deposition caused by influx of mineral-rich water in early summer, and of nekron-mud in autumn and early winter. Thanks to the small size and shelter of the lake, these annual layers were preserved in long series, and have permitted the construction of a geochronology which reaches to the present day. In terms of this all other stratigraphic, climatic and vegetational events have been dated. More also than this: the recognition of annual layering has permitted Welten to express his results in terms of absolute rates of pollen deposition per unit area of lake surface. He has thus provided the test we have long awaited, of the validity of the standards of reckoning, long accepted faute de mieux, such as grains per cent of the total tree pollen, or grains per unit area of microscopic preparation.

There has always hitherto been much room for doubt how far the parallel and analogous changes in forest history in the Alps and in regions far afield were indeed synchronous, but Welten's new chronology goes far to set such doubts at rest. His date of 5400 B.c. for the sudden extension of the mixed oak forest in Faulenseemoos corresponds closely with that given by Fromm for the equivalent vegetational change in Angermannland. Confirmation of Welten's own chronological series comes from such results as the estimated age of the end of the Neolithic period at 1800 B.C., a close agreement with archæological estimates.

From the relative and absolute amounts of the lake chalk, organic mud and mineral matter, Welten is able to deduce climatic conditions, as also from the vegetational changes recorded by the pollen analyses. The regional vegetational history begins with the early dwarf-willow stages when the soil was open to erosion; the middle dwarf-willow - grass stages with closed ground cover and abundant Helianthemum alpestre ; the third willow stage with extension of the dwarf-birch and entry of the tree birches. Continued climatic improvement then led to an explosive but temporary expansion of the sea-buckthorn (Hippophoe rhamnoides) in conditions of slight competition, and then to successive phases of dominance by Betula pubescens and $B$. verrucosa. About 6150 B.c. a climatic retrogression broke the trend of general amelioration, but thereafter the open pine woods were rapidly succeeded by hazel scrub, and afterwards by mixed oak forest. About 3200 B.c. beech became dominant, and thereafter persisted, in varying relation to the spruce and mixed oak forest, as an important forest component to the present day. Early human activity is reflected in the diagrams not only by changes in the pollen frequency, but by the appearance of cereal pollen, by increase in mineral deposition in the lake, and by the pollen of such introduced trees as the walnut. These elaborate and exactly dated diagrams will be of the utmost value to the study of quaternary history in central and southern Europe, and the work as a whole deserves our own attention and emulation.

Such studies as this show the manifold indexes by which the deposits of former lakes may be made to yield the secrets of their history, and of the vegetational changes which they and the surrounding areas have suffered through the long period since the Ice Age. Apart from its own great intrinsic interest, such knowledge affects biological and elimatic issues of great and general importance, and constitutes a background essential to our attempts to understand the meaning of present vegetational types and present vegetational processes of lake biology. It is very much in the interest of British biology that means should be found to pursue such studies as these in our own lake basins, where at least equally rich rewards may be expected. Let us appoint and train these archivists.

H. GoDwIN.

1 Pollenanalytische, stratigraphische und geochronologische Untersuchungen aus dem Faulenseemoos bei Spiez. Von Max Welten. Zürich.) Heft 21. Pp. 201. (Bern: Hans Huber, 1944.) 12.50 Schw. francs.

\section{OBITUARIES}

\section{Dr. Alexander Sand, F.R.S.}

In the completely unforeseen death of Alexander Sand at the age of forty-three, comparative physiology suffered a very severe loss. Not only was his later work distinguished in a remarkable degree, but so much more of the same calibre might have been expected from him in the next twenty years.

Sand's early work dealt with changes in electrical resistance accompanying the death of cells, and with the relation of combined nitrogen to the physiological activity of Azotobacter. After his appointment as lecturer in zoology at Capetown under Hogben, he undertook a series of experimental studies dealing 
with invertebrates, the first of which described the relation of electrolytes to the cardiac rhythm of Jasus and Octopus, the others the respiratory exchange of certain arthropods (a crab and a scorpion) and of a marine worm (Bispira). This work was accompanied by determinations which were made by Sand of the hydrogen-ion concentration and oxygen-content of samples of sea water, in connexion with studies undertaken by colleagues. His next work concerned chamæleons. After a peculiarly neat and illuminating paper describing adequately, for the first time, the mechanism of the projection of the chamæleon's tongue (1933), he published another important paper describing the bionomics and physiology of the pigmentary activity of this animal. These papers were followed by a contribution to Biological Reviews on the comparative physiology of colour-resporse in reptiles and fishes.

After Sand's return from Cape Town to England he was appointed physiologist to the Marine Biological Laboratory at Plymouth, and thenceforward his interests were devoted to experiments on fishes, dealing primarily with certain of their sense organs. He published in 1936, in collaboration with James Gray, papers on the locomotory rhythm and spinal reflexes of the dogfish. After a preparatory period, during which he mastered the complex and delicate apparatus required, Sand attained the height of his ability and began his final work on the sense organs. This work, carried out partly in collaboration with Otto Löwenstein, involved a series of precise and beautiful experiments, and resulted in a most marked and definite advance in our knowledge not only of the labyrinth of fishes, but also of the lateral sense organs and of the peculiar ampullæ of Lorenzini. It is this last body of work for which Sand will be longest remembered, and which entitles him to rank high among British comparative physiologists. He was elected to the Royal Society in 1944. Two of his collaborators, Gray and Löwenstein, have already been mentioned; but during his whole career Sand also published joint papers with Lancelot Hogben, Enid Charles and others.

One of Sand's outstanding characteristics, the precision of his use of experimental apparatus, came out not only in his research work but also in his teaching. During his years at Cape Town he conducted a class in comparative physiology which was distinguished by its finished and flawless demonstrations. Sand served in the Royal Navy during the Second World War, and died on July 11, 1945. His death has come as a great shock to his many friends.

T. A. Stephenson.

\section{Prof. Ludwik Wertenstein}

THE tragic death of Prof. Ludwik Wertenstein, who was killed in January during the battle for Budapest, deprives Poland of one of its leading men of science, and represents a grievous loss to physicists generally, among whom he had many personal friends.

Born in Warsaw in 1885, Wertenstein received his early education there and entered the University, which he had, however, to leave in 1906, after one year of study, because of taking part in the students' protest strike against the policy of the Tzarist regime. He went to Paris, where he entered the Sorbonne and began to work in Madame Curie's laboratory. His first scientific work was published in 1909 and was soon followed by a series of papers dealing mainly with the properties of recoil atoms of radioactive elements, a subject which, with his usual thoroughness, he pursued and studied for many years. He measured the range, ionization and charge of recoil atoms, and some conclusions of these experiments were recently confirmed in the study of the ionizing properties of fission fragments.

In 1913, the Scientific Society of Warsaw founded, under the auspices of Madame Curie, the Radiological Laboratory, where research work on radioactivity was to be centred. Madame Curie sent her two most outstanding pupils, Danysz and Wertenstein, to Warsaw to direct the work there. After the death of Danysz in 1914, Wertenstein became director of the Laboratory, and he remained there until its destruction in 1939. In 1919 he was appointed to the chair of radioactivity at the Free University of Poland, where he later founded the Laboratory of Atomic Physics. Except for the period 1925-26, which he spent at the Cavendish Laboratory under the late Lord Rutherford, all his scientific work was done in these two laboratories. Despite the constant difficulties and limitations due to lack of funds, he managed to create a centre of research which gained a high reputation abroad, and to form a school from which came a number of young men of science of standing.

Most of Wertenstein's scientific work was in the field of radioactivity; he made a detailed study of the properties of radon, found new methods for its purification, investigated its condensation properties, measured its vapour pressure and ionization potential, and determined the volume of one curie, an important quantity in radioactivity. But his interests embraced. many other branches of physies, and among the large number of papers he published are some on such divergent subjects as vacuum technique, photochemical law and isotope separation. In recent years, he concentrated mainly on nuclear physics, in particular on problems of inelastic scattering of neutrons, photonuclear effects and fission. His last paper, on gaseous fission products, published in Nature of December 29, 1939, was sent out of Poland when it was already occupied by the Germans.

Apart from pure scientific work, Wertenstein took an active part in the organization and popularization of science in Poland. He was a member of the Academy of Technical Sciences, and president of the Physical Society of Warsaw. His agile, penetrating and critical mind, swift reasoning, and almost uncanny facility for operating with figures mentally, made every discussion in the Physical Society a lively and exciting event. His was a most remarkable and versatile mind; apart from being a brilliant experimenter and highly skilled in various techniques, he was an excellent theoretician and had a deep knowledge of mathernatics. He spoke fluently many languages, was a classical scholar and had great literary talent. His quickness and wit, combined with a deep sense of humour, made him most popular at all scientific and social gatherings. An excellent speaker, he had a particular gift of presenting difficult problems in a simple manner, and his public lectures -masterpieces in language and composition-always attracted large audiences. His articles in various magazines and Sunday papers contributed a great deal to the popularization of science in Poland. He translated a number of books into Polish, the last being Madame Curie's "Radioactivite" ; the translation of this was just finished when war broke out, 